\title{
Karakteristik Wake Area Akibat Efek Penggunaan Vortex Generator di Belakang Wing Airfoil Naca 43018
}

\author{
Setyo Hariyadi S.P. ${ }^{1,2}$, Wawan Aries Widodo ${ }^{2}$ \\ ${ }^{1}$ Politeknik Penerbangan Surabaya \\ Jemur Andayani I/73 Wonocolo Surabaya 60236 \\ ${ }^{2}$ Laboratorium Mekanika dan Mesin Fluida \\ Jurusan Teknik Mesin, Fakultas Teknologi Industri, Institut Teknologi Sepuluh Nopember (ITS) \\ J1. Arief Rahman Hakim, Surabaya 60111 Indonesia \\ e-mail: hudzaifahsetyo@gmail.com
}

\begin{abstract}
Abstrak
Pada aliran yang melintasi suatu airfoil terdapat fenomena separasi, yakni ketika momentum aliran sudah tidak mampu lagi mengatasi adverse pressure gradien. Selanjutnya separasi ini akan diikuti dengan timbulnya daerah wake pada daerah di belakang airfoil yang mengakibatkan naiknya drag force dan menurunnya lift force. Untuk mengurangi hal tersebut maka vortex generator diletakkan pada sisi atas airfoil untuk mempercepat terbentuknya turbulent boundary layer sehingga dapat menunda separasi dan memperkecil daerah wake.

Efektivitas dari vortex generator dipengaruhi oleh penempatan, ketinggian, dan interval antar vortex generator. Untuk mendapatkan hasil yang optimal, drag yang dihasilkan oleh vortex generator itu sendiri harus dikurangi. Untuk itu profil dari vortex generator yang digunakan harus sedemikian rupa sehingga drag yang dihasilkan dapat dikurangi tanpa menurunkan performasi dari airfoil tersebut. Oleh karena itu, penelitian ini dilakukan untuk melihat pengaruh penambahan vortex generator terhadap unjuk kerja airfoil melalui metode eksperimen. Tujuan penelitian ini adalah membandingkan karakteristik aliran fluida plain wing dan dengan penambahan vortex generator. Profil vortex generator yang digunakan adalah flat plate vortex generator dengan konfigurasi straight dan ditempatkan pada $x / c=$ $10 \%$ dan $20 \%$ arah chord line dari leading edge. Variasi yang digunakan adalah bilangan Reynolds $(R e)$, sudut serang $(\alpha)$ dan peletakan vortex generator pada airfoil. Kecepatan freestream yang digunakan yaitu kecepatan $12 \mathrm{~m} / \mathrm{s}$ atau $R e=7,65 \times 10^{5}$ dan kecepatan $17 \mathrm{~m} / \mathrm{s}$ atau $R e=9 \times 105$, dan pada sudut serang $(\alpha) 0^{\circ}, 3^{\circ}, 6^{\circ}, 9^{\circ}, 12^{\circ}, 15^{\circ}, 19^{\circ}$, dan $20^{\circ}$.

Hasil penelitian ini menunjukkan bahwa terjadi peningkatan performansi dari airfoil NACA 43018 dengan penambahan vortex generator dibandingkan dengan tanpa vortex generator. Adanya vortex generator, mempercepat perubahan dari aliran laminar ke turbulen. Separasi dapat tertunda dengan adanya vortex generator.
\end{abstract}

Kata kunci: airfoil NACA 43018, vortex generator, separasi, wake

\section{PENDAHULUAN}

Pesawat terbang dirancang sedemikian rupa sehingga hambatan udaranya sekecil mungkin. Dari semua desain pesawat, pasti yang diinginkan adalah lift setinggi-tingginya. Untuk mendapatkan lift yang setinggi-tingginya membutuhkan angle of attack $(\alpha)$ yang tinggi 
juga. Pada saat $\alpha$ tinggi akan menimbulkan gaya drag yang meningkat juga. Salah satu cara untuk mengatasi gaya drag ini adalah menggunakan vortex generator pada bagian tertentu dari pesawat terbang. Vortex generator menunda terjadinya separasi aliran dan aerodynamic stalling sekaligus menjaga aliran terutama di atas wing/sayap agar tetap steady.

Vortex generator $(V G)$ adalah suatu alat yang dapat mempercepat terjadinya transisi dari laminar boundary layer menjadi turbulen boundary layer. Ada berbagai jenis vortex generator antara lain vane, delta wing, dan triangular. Aliran turbulen boundary layer yang dibangkitkan ini diharapkan dapat meningkatkan momentum aliran sehingga lebih mampu menahan adverse pressure gradien dan menunda separasi. Vortex generator ini sudah banyak diterapkan di berbagai macam pesawat komersial. Salah satu yang menggunakannya adalah pada pesawat boeing yaitu menggunakan vortex generator jenis plat datar.

Velte [1] menggunakan bump (gundukan) untuk melihat pengaruh penambahan vortex generator terhadap karakteristik aliran di daerah downstream. Vortex generator yang dipakai adalah bentuk triangular dan ketinggian sebesar $1 \delta, 0.4 \delta$, dan $0.2 \delta$ dengan $R e=2 \times 10^{4}$, dipasang pada posisi $42 \%$ bump chord dan angle of incidence $18^{\circ}$. Hasilnya menunjukkan kenaikan profil kecepatan di daerah dekat batas solid surface. Separasi di daerah downstream juga dapat ditunda secara efektif pada penggunaan vortex generator. Pada penelitiannya itu, digunakan counter rotating vortex generator pada sebuah bump di wind tunnel. Penelitian ini bertujuan untuk menginvestigasi efek dari vortex generator terhadap separasi, reynold number rendah, turbulent boundary layer terkait dengan ketahanan terhadap adverse pressure gradient dengan menggunakan free stream velocity sebesar $1 \mathrm{~m} / \mathrm{s}$ untuk menentukan geometri vortex generator yang paling optimal. Sementara itu, Anand et al [2] meneliti efektifitas vortex generator jenis triangle vortex generator yang diletakkan pada $10 \%$ chord length pada airfoil jenis NACA 0012. Berdasarkan penelitian ini didapatkan hasil yaitu penggunaan vortex generator dapat menunda separasi pada dinding airfoil. Zhen [3] juga melakukan penelitian terhadap beberapa bentuk vortex generator dengan ketinggian yang berbeda dan didapatkan bahwa bentuk rectangular dan curve-edge vortex generator memiliki efektifitas yang lebih tinggi daripada triangular dalam menaikkan gaya angkat (lift force).

Pada penelitian kali ini, akan digunakan airfoil NACA 43018 dengan vortex generator berupa rectangular flat plate dengan susunan straight. Dengan adanya vortex generator ini diharapkan dapat menaikkan momentum aliran di dekat dinding airfoil sehingga dapat lebih tahan terhadap adverse pressure gradien dan menunda separasi. Dengan tertundanya separasi akan menaikkan lift force dan menurunkan drag force pada airfoil sehingga dapat meningkatkan performansi airfoil tersebut [4]. Dengan performa airfoil yang baik akan menghemat bahan bakar pesawat tersebut saat beroperasi

\section{METODE PENELITIAN}

Model sayap yang digunakan dalam percobaan ini adalah sayap dengan profil airfoil NACA 43018 dengan modifikasi penambahan vortex generator bagian atas untuk mengetahui pengaruh penambahan vortex generator dibandingkan tanpa model sayap tanpa vortex generator. 


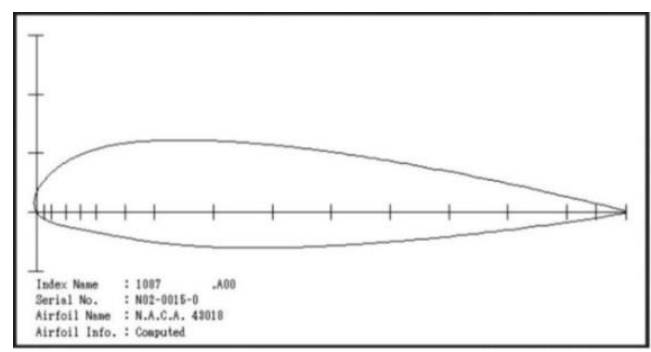

Gambar 1. Profil airfoil NACA 43018 [5]

\section{Jenis airfoil dan kondisi ruangan}

Jenis Airfoil

Tekanan ruangan

Temperatur ruangan
: NACA 43018

: $760 \mathrm{mmHg}$

$$
: 30^{0} \mathrm{C}
$$

\section{Parameter Vortex Generator}

Tabel 1. Parameter Vortex Generator 43018

\begin{tabular}{|c|c|c|}
\hline Paramater & Eksperimen & \\
\hline Shape & Rectangular & \\
\hline $\mathrm{h}$ & $0.0086 \mathrm{c}$ & Anand (2010) \\
\hline $1 / \mathrm{h}$ & 3 & Lin (1999) \\
\hline AoA & $\begin{array}{l}0^{\mathrm{o}}, 3^{\mathrm{o}}, 6^{\mathrm{o}}, 9^{\mathrm{o}}, 12^{\mathrm{o}}, \\
15^{\mathrm{o}}, 19^{\mathrm{o}}, \text { dan } 20^{\mathrm{o}}\end{array}$ & \\
\hline $\mathrm{x} / \mathrm{c}$ & $10 \%, 20 \%$ & H. Shan et al, (2007) \\
\hline c & $200 \mathrm{~mm}$ & \\
\hline $\mathrm{d}$ & $0,182 c$ & Anand (2010) \\
\hline Susunan & Straigh & \\
\hline $\mathrm{V}_{\infty}$ & $12 \mathrm{~m} / \mathrm{s}, 17 \mathrm{~m} / \mathrm{s}$ & \\
\hline & $\begin{array}{l}\text { Base } \\
\text { separ }\end{array}$ & \\
\hline
\end{tabular}

Gambar 2. Definisi vane-type passive VG devices 


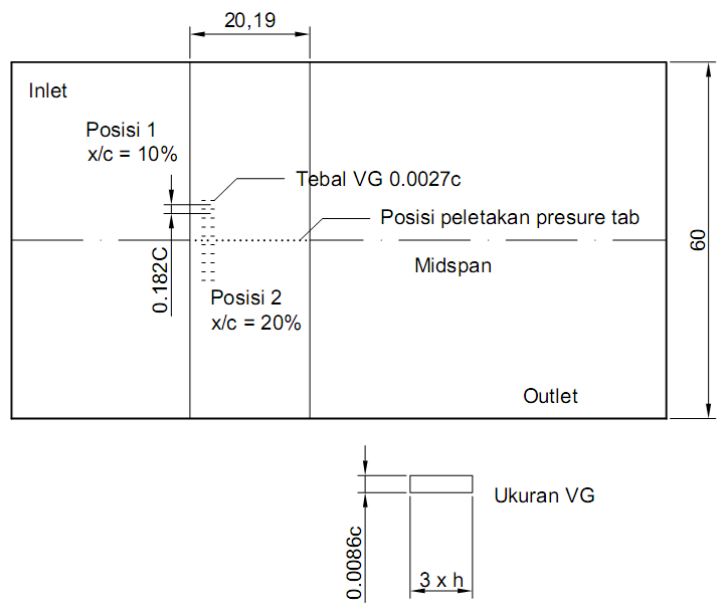

Gambar 3. Posisi peletakan VG pada penelitian eksperimen

Penelitian ini menggunakan wind tunnel jenis open circuit untuk menguji benda dalam skala model, dimana udara yang dialirkan ke dalamnya langsung bebas dilepas ke udara bebas setelah melalui test section. Hal ini disebabkan pengukuran sebenarnya cukup sulit dan membutuhkan biaya yang mahal. Oleh karena itu,wind tunnel dibuat dengan kondisi yang mendekati kenyataan sehingga hasil yang didapatkan cukup akurat. Wind tunnel ini memiliki spesifikasi sebagai berikut :

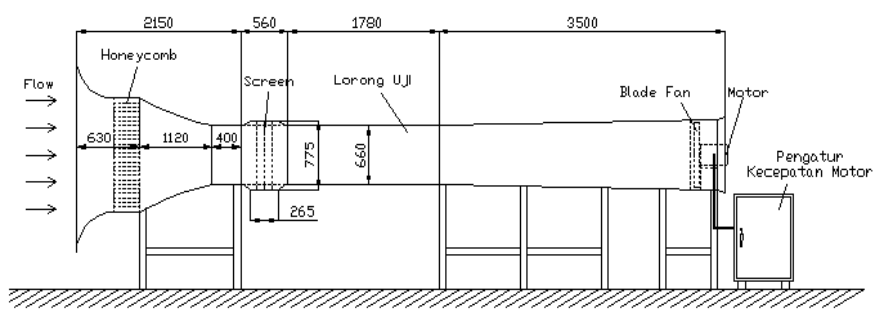

Gambar 4. Skema dan dimensi wind tunnel

\section{HASIL PENELITIAN DAN PEMBAHASAN}

\section{Analisis Distribusi Kecepatan}

Gambar 5 menunjukkan hasil pengukuran distribusi kecepatan pada daerah belakang airfoil pada $\alpha=0^{\circ}$, dan $19^{\circ}$ dengan $R e=7,65 \times 10^{5}$ dimana didapatkan lebar wake yang relatif bervariasi akan tetapi dengan posisi yang bergeser semakin ke depan seiring dengan meningkatnya sudut serang. Pada sudut serang $0^{\circ}$ lebar wake yang terjadi pada y yang terjadi sebesar $45,5 \mathrm{~mm}$ dengan nilai $u$ freestream minimum sudut serang $0^{\circ}$ sebesar 0,93 . Hal ini menunjukkan bahwa dengan adanya penambahan sudut serang, momentum aliran masih mampu melawan gaya gesek permukaan dan adverse pressure gradient. Separasi yang terjadi dengan penambahan sudut serang tidak mengalami perubahan sehingga total drag force yang dihasilkan belum mengalami peningkatan yang berarti. 


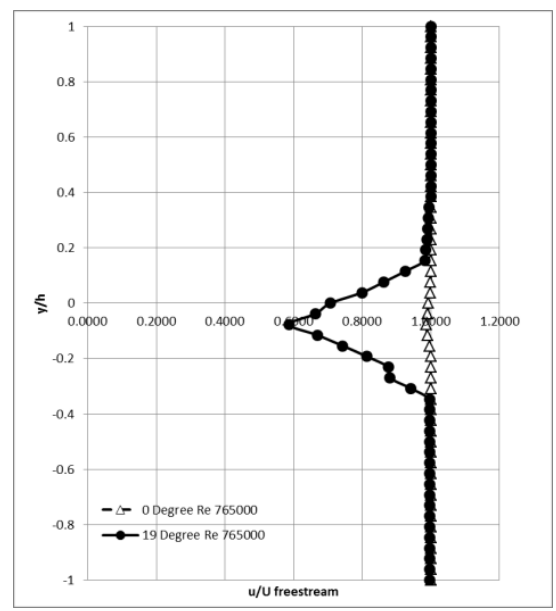

Gambar 5. Distribusi kecepatan untuk plain Airfoilpada sudut serang $(\alpha) 0^{\circ}$, dan $19^{\circ}$ pada $R e=7,65 \times 10^{5}$

Berdasarkan gambar 5 distribusi kecepatan pada sudut serang $19^{\circ}$ pada $R e=7,65$ x $10^{5}$ terlihat bahwa lebar wake akan semakin membesar seiring dengan meningkatnya sudut serang. Pada sudut serang $19^{\circ}$, lebar wake yang terjadi pada arah y yang terjadi sebesar 104 mm dengan nilai $u_{\text {freestream }}$ minimum sebesar 0,5 . Hal ini menunjukkan bahwa dengan adanya perubahan sudut serang menyebabkan gradient kontur meningkat dan akan berakibat pada gradient tekanan dan pengurangan momentum sehingga mengakibatkan titik separasi akan semakin ke depan. Hal ini juga mengakibatkan total drag force yang dihasilkan mengalami kenaikan.

\section{Perbandingan Distribusi Kecepatan Plain Airfoil dengan Dua Reynolds Number Berbeda}

Gambar 6 menunjukkan bahwa lebar wake akan semakin sempit seiring dengan meningkatnya Reynolds number. Hal ini menunjukkan bahwa dengan adanya penambahan kecepatan aliran, momentum aliran yang dihasilkan akan mampu mengatasi gaya gesek dan adverse pressure gradientsehingga separasi aliran dapat tertunda dan berakibat distribusi kecepatan akan semakin sempit.

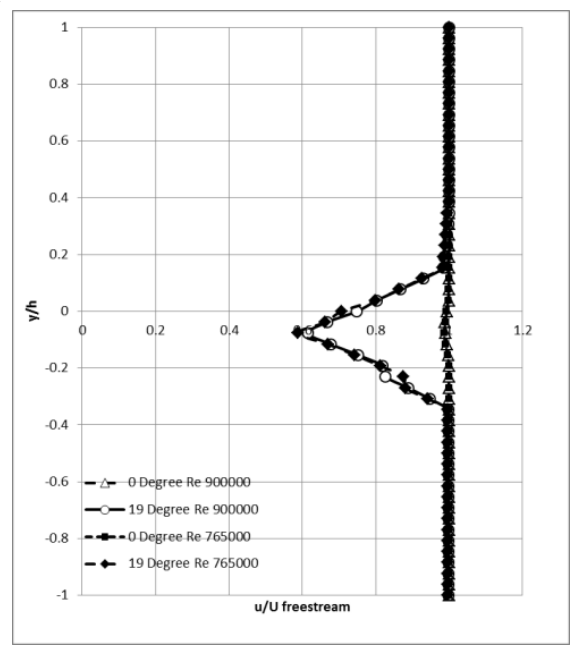

Gambar 6. Distribusi kecepatan untuk plain Airfoil pada sudut serang $(\alpha) 0^{\circ}$ dan $19^{\circ}$ pada $\operatorname{Re}=7,65 \times 10^{5}$ dan $9 x$ $10^{5}$

Analisis Distribusi Kecepatan Pada Airfoil dengan Vortex Generator

Pada gambar 7 diperlihatkan hasil pengukuran distribusi kecepatan pada daerah belakang airfoil dengan vortex generator dimana didapatkan lebar wake yang relatif sama seiring dengan 
meningkatnya sudut serang. Pada sudut serang $0^{\circ}$, lebar wake yang terjadi pada arah $y / h$ yang terjadi sebesar 45,5 dengan nilai u/ufreestream minimum sebesar 0,93, Hal ini menunjukkan bahwa dengan adanya penambahan sudut serang, momentum aliran masih mampu melawan gaya gesek permukaan dan adverse pressure gradient. Separasi yang terjadi dengan penambahan sudut serang tidak mengalami perubahan sehingga total drag force yang dihasilkan belum mengalami peningkatan yang berarti.

Gambar 8 menunjukkan bahwa lebar wake akan semakin membesar seiring dengan meningkatnya sudut serang. Pada sudut serang $19^{\circ}$, lebar wake yang terjadi pada arah $y / h$ yang terjadi sebesar $78 \mathrm{~mm}$ dengan nilai $u_{\text {ufreestream }}$ minimum sebesar 0,93 . Hal ini menunjukkan bahwa dengan adanya perubahan sudut serang kemampuan momentum aliran untuk melawan gaya gesek permukaan dan adverse pressure gradient mulai berkurang mengakibatkan titik separasi akan berubah. Hal ini juga mengakibatkan total drag force yang dihasilkan mengalami kenaikan.

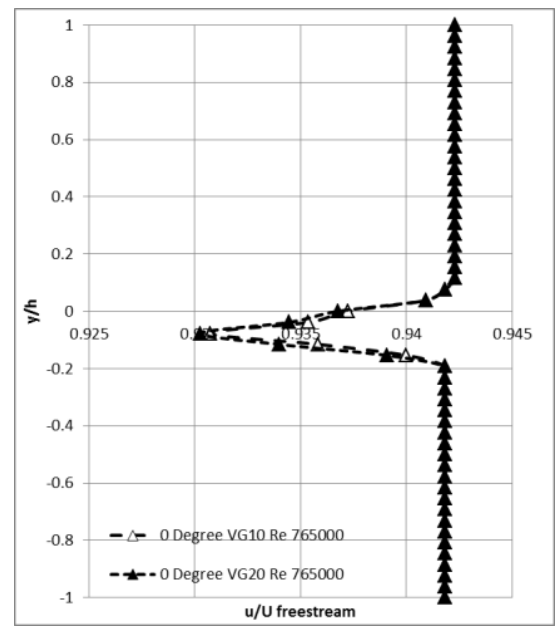

Gambar 7. Distribusi kecepatan untuk Airfoil dengan $V G 10 \%$ dan $20 \%$ pada sudut serang $(\alpha) 0^{\circ}$ pada $\operatorname{Re}=7,65$ $\mathrm{x} 10^{5}$

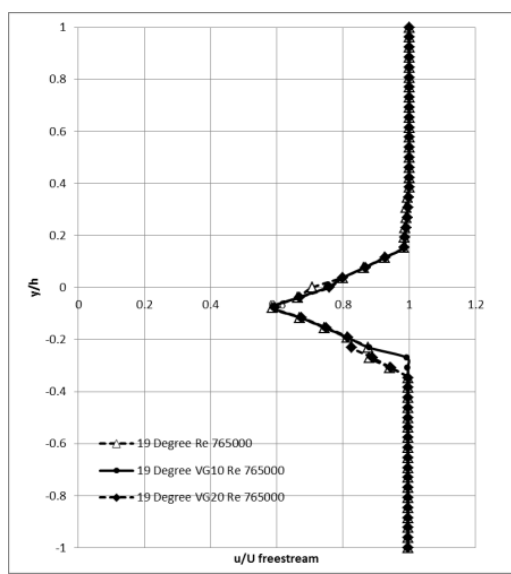

Gambar 8. Distribusi kecepatan untuk airfoil dengan $V G$ pada sudut serang $(\alpha) 19^{\circ}$ pada $R e=7,65 \times 10^{5}$

\section{Perbandingan Distribusi Kecepatan Airfoil dengan $V G$ dengan Dua Reynolds Number Berbeda}

Pada gambar 9 menunjukkan bahwa lebar wake akan semakin sempit seiring dengan meningkatnya Reynolds number. Hal ini menunjukkan bahwa dengan adanya penambahan kecepatan aliran, momentum aliran yang dihasilkan akan mampu mengatasi gaya gesek dan adverse pressure gradientsehingga separasi aliran dapat tertunda dan berakibat daerah wake akan semakin sempit. 


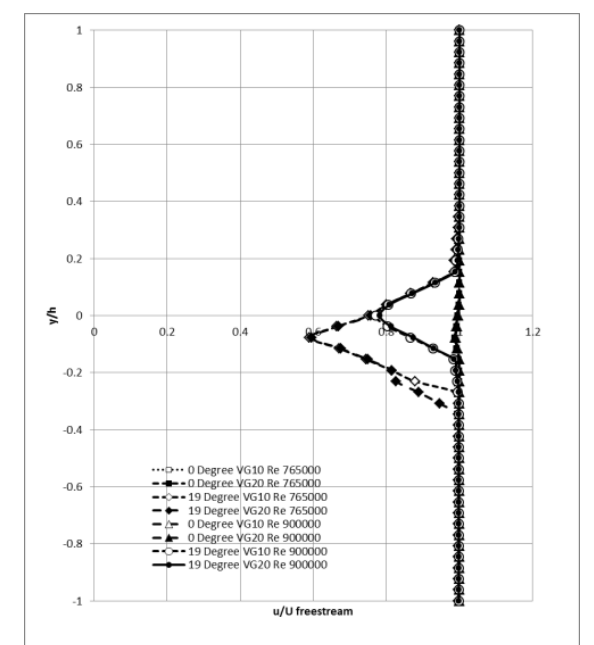

Gambar 9. Distribusi kecepatan untuk Airfoildengan vortex generator pada sudut serang $(\alpha) 0^{\circ} \mathrm{dan} 19^{\circ}$ pada $R e=$ $7,65 \times 10^{5}$ dan $9 \times 10^{5}$

\section{Perbandingan Distribusi Kecepatan antara Plain Airfoil dan Airfoil dengan VG (Eksperimen)}

Pada gambar 10, lebar wake pada airfoil dengan vortex generator relatif lebih sempit dibandingkan pada plain airfoil. Hal ini menunjukkan bahwa dengan penambahan vortex generator,aliran dekat dengan permukaan atas airfoil mengalami peningkatan kecepatan sehingga dapat meningkatkan momentum dari aliran sehingga menyebabkan lebar wake semakin sempit. Dengan kata lain penambahan vortex generator ini sudah memberikan efek pada wake airfoil dengan sudut serang $0^{\circ}$ meskipun efek yang ditimbulkan belum menunjukkan hasil yang signifikan.

Gambar 11 menunjukkan bahwa pada sudut serang $19^{\circ}$ dengan penambahan vortex generator lebar wake akan relatif semakin sempit daripada pada plain airfoil. Hal ini menunjukkan bahwa penambahan vortex generator akan menyebabkan aliran semakin turbulen sehingga lebih mampu menahan adverse pressure gradientdan menyebabkan lebar wake di belakang airfoil semakin sempit.

Pada gambar 4.11 lebar wake airfoil dengan vortex generator lebih sempit daripada pada plain airfoil. Hal ini menunjukkan bahwa pada sudut serang tinggi airfoil dengan vortex generator dapat meningkatkan kecepatan aliran dekat dengan permukaan atas dari airfoil sehingga dapat meningkatkan momentum aliran yang lebih tahan terhadap gaya gesek kontur dan adverse pressure gradient. Hal ini menyebabkan separasi yang semakin tertunda akibat penambahan momentum aliran yang mampu melawan adverse pressure gradient yang terjadi sehingga lebar wake akan semakin sempit.

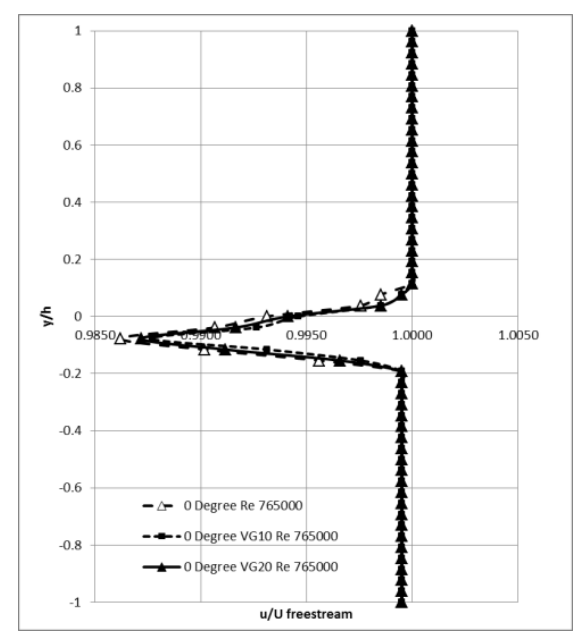

(a) 


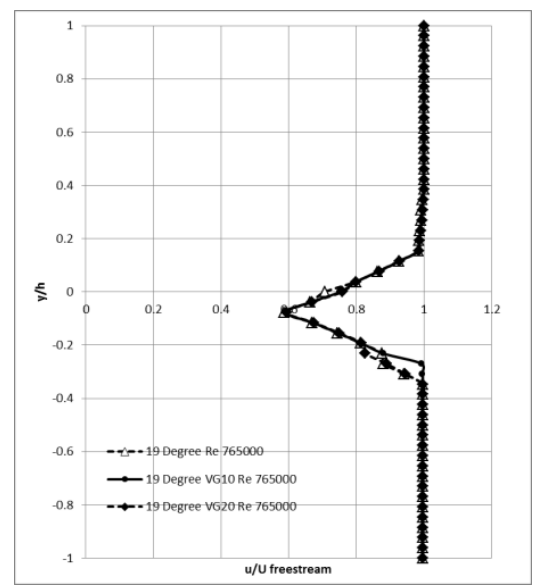

(b)

Gambar 10. Perbandingan distribusi kecepatan plain Airfoil dan Airfoildengan VG $10 \%$ dan $20 \%$ pada $R e=$ $7.65 \times 10^{5}$ pada sudut serang $(\alpha) 0^{\circ}$ dan $19^{\circ}$

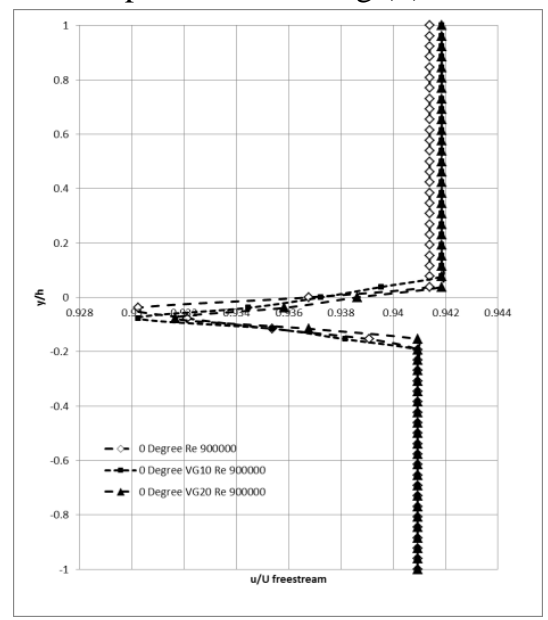

(a)

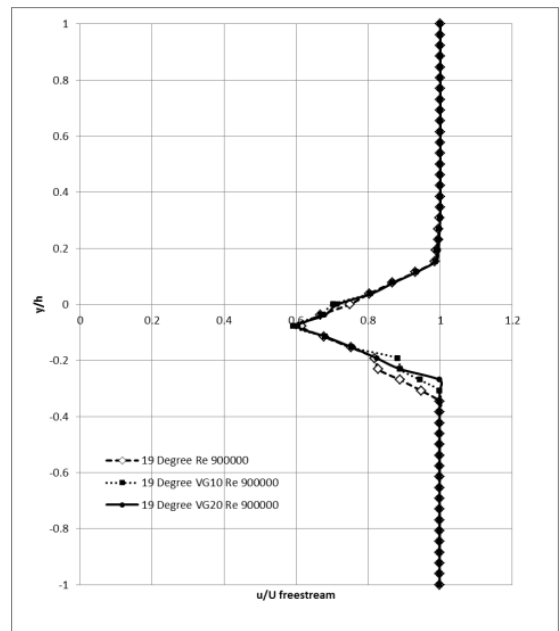

(b)

Gambar 4.11. Perbandingan distribusi kecepatan plain airfoil dan Airfoildengan $V G$ padaRe $=9 \times 10^{5}$ pada sudut serang $(\alpha) 19^{\circ}$

\section{KESIMPULAN}

Dari penelitian ini maka dapat ditarik kesimpulan antara lain:

1. Dengan penambahan vortex generator,aliran dekat dengan permukaan atas airfoil mengalami peningkatan kecepatan sehingga dapat meningkatkan momentum dari aliran sehingga menyebabkan lebar wake semakin sempit 
2. Penambahan vortex generator akan menyebabkan aliran semakin turbulen sehingga lebih mampu menahan adverse pressure gradientdan menyebabkan lebar wake di belakang airfoil semakin sempit

\section{REFERENSI}

[1] Anand, U., Shudakar, Y., Thileopanragu, R., Gopinathan, V.T., dan Rajasokar, R. 2010. Passive Flow Control Over NACA 0012 Airfoil Using Vortex Generator, India: Department of Aerospace Engineering IIT Madras.

[2] Anderson, John D. Jr., (1988), Fundamental of Aerodynamics. Singapore, McGraw-Hill, Inc.

[3] H. Shan et al.(2007), Numerical Study of Passive and Active Flow Separation Control Over NACA 0012 Airfoil, Science Direct

[4] Lin, John. C.,(2002), Review of research on low-profile vortex generators to control boundary-layer separation Flow, Physics and Control Branch, NASA Langley Research Center, Hampton, VA 23681-2199, USA

[5] Nita, Mihaela Florentina (2008), Aircraft Design Studies Based on the ATR 72, Department of Automotive and Aeronautical Engineering Hamburg University of Applied Sciences

[6] Velte, C.M., Hansen, M.O.L., dan Jonck, K. (2007), Experimental and Numerical Investigation of The Performance of Vortex Generator, Technical University of Denmark $75: 012030$

[7] Zhen, Tan Kar, Ahmad, Kamarul Arifin., Zubair, Muhammed, (2010), Experimental and Numerical Investigation of the Effects of Passive Vortex Generators on Aludra UAV Performance, Journal of Aeronautics, School of Aerospace Engineering, University Sains Malaysia, Nibong Tebal 14300, Malaysia 